\title{
Systemic Lupus Erythematosus in Males
}

\author{
A Study of 107 Latin American Patients \\ Jose F. Molina, M.D., Cristina Drenkard, M.D., Javier Molina, M.D., Mario H. Cardiel, M.D., \\ Oscar Uribe, M.D., Juan-Manuel Anaya, M.D., Luis J. Gomez, M.D., Oscar Felipe, M.D., \\ Luis A. Ramirez, M.D., AND Donato Alarcon-Segovia, M.D.
}

\section{Introduction}

Systemic lupus erythematosus (SLE) is a clinically heterogeneous autoimmune disease of unknown etiology in which multiple factors play important roles. One of its most striking characteristics is the higher prevalence among young women $(31,41,47)$, which suggests a key role of sex hormones (34). Sex distribution before puberty and late in life does not show the marked preponderance of females seen in early adulthood $(9,43,45)$, and some family studies of SLE have shown a male predominance $(17,42)$. Additionally, the disease activity has been shown to be associated with pregnancy, the postpartum period, and occasionally the use of estrogen-containing oral contraceptives $(37,58,63)$. Furthermore, the association of SLE in males with Klinefelter syndrome is well known $(22,23,57,61)$. On the other hand, androgens, antiestrogenic agents, danazol, and ovariectomy have been reported to have beneficial effects on disease activity $(38,52)$.

The obvious question is whether the disease manifests itself differently in males. Some investigators $(6,11,12,16,21,24,28,35,39,50,59,62,65,68,69$, $70,71)$ claim that it does and that a much more aggressive course of the disease and a higher mor-

From the Department of Internal Medicine (JFM, LJG), Universidad Pontificia Bolivariana; the Department of Internal Medicine, Section of Rheumatology (JM, OU, OF, LAR), Universidad de Antioquia; the Section of Immunology (JMA), Corporación para Investigaciones Biológicas, Medellín, Colombia; and the Department of Immunology and Rheumatology (CD, MHC, DAS), Instituto Nacional de la Nutrición Salvador Zubirán, México City, México.

Jose F. Molina's current address is the Section of Rheumatology, Department of Medicine, Louisiana State University Medical Center, New Orleans, Louisiana.

Mario H. Cardiel is the recipient of the Gustavo Baz Prada Nominal Chair.

Abbreviations used in this paper: ACR, American College of Rheumatology; SLE, systemic lupus erythematosus.

Address reprint requests to: Javier Molina, MD, Calle 4 Sur \#43 AA 26, Medellín, Colombia. bidity rate can be observed among male patients with SLE. In addition, differences in race and ethnicity may have a role in the expression of the disease $(28,31,44,51)$.

We undertook a cross-sectional study of 107 Latin American men from a series of 1,316 patients with SLE seen in 3 referral centers in Colombia and Mexico. The main purposes of the present study were to determine the clinical and laboratory features in our male SLE patients, and to compare them with those of our female SLE patients.

\section{Patients and Methods}

\section{Patient population}

This was a cross-sectional, multicenter, and binational study of 107 male patients with SLE compared with a group of 1,209 female patients with SLE who were treated and followed up in the rheumatology clinics of Hospital San Vicente de Paul, Universidad de Antioquia, and Clinica Leon XIII, Medellín, Colombia, and Instituto Nacional de la Nutrición Salvador Zubirán, Mexico City, Mexico, either as inpatients or outpatients between 1972 and 1993. Six hundred and forty-nine (49\%) patients were seen in Colombia (73 males, 576 females) and 667 (51\%) were seen in Mexico (34 males, 633 females). All patients met the American College of Rheumatology (ACR) revised criteria for the classification of SLE (67). None had drug-induced SLE. The age at diagnosis was the date at which an individual patient fulfilled at least 4 ACR criteria for SLE.

\section{Clinical and laboratory manifestations}

All relevant data on background, history, physical findings, and laboratory investigations of the patients were obtained from their medical records. The following clinical and laboratory manifestations of SLE were examined: 1) Arthritis: non-erosive arthritis involving 2 or more peripheral joints, characterized by tenderness, swelling, or effusion. 2) Joint deformity, chiefly pseudorheumatoid hand with swan neck deformities (Jaccoud-like arthritis). 3) Skin involvement. 4) Raynaud phenomenon. 5) Renal involvement: 5a) a positive renal biopsy result, $5 \mathrm{~b}$ ) active urinary sediment, or $5 \mathrm{c}$ ) proteinuria $>500 \mathrm{mg} / 24 \mathrm{~h}$; nephrotic syndrome defined as $>3.5 \mathrm{~g}$ of proteinuria in a 24-hour specimen or the presence of proteinuria ( $3+$ to $4+$ ) with a serum albumin level of 
$<2.8$ g/dL. 6) Neurologic involvement: 6a) seizures without other definable cause, or 6b) psychosis without other definable cause, or $6 \mathrm{c}$ ) other condition such as peripheral neuropathy, stroke, transverse myelitis, chorea, or other CNS lesions directly attributable to SLE in the absence of other causes. 7) Pleuritis: pleural rub and/or effusion and/or typical pleuritic pain. 8) Pericarditis documented by electrocardiogram, rub, or evidence of pericardial effusion. 9) and 10) Arterial or venous thrombosis: diagnosed on clinical grounds and confirmed by complementary tests. 11) Autoimmune hemolytic anemia, with hematocrit $<35 \%$ and reticulocyte count $>4 \%$. 12) Leukopenia, white cell count $<4,000 / \mathrm{mm}^{3}$. 13) Thrombocytopenia, platelet count $<100,000 / \mathrm{mm}^{3}$. 14) Antinuclear antibodies determined by indirect immunofluorescence using mouse liver or Hep-2 cells as substrate. 15) Anti-dsDNA antibodies determined with Farr's technique or by indirect immunofluorescence with Crithidia luciliae as substrate. 16-19) Precipitating antibodies to extractable nuclear antigens, including Sm, U1-RNP, Ro/SSA, and La/SSB, detected by double immunodiffusion. 20-22) Anticardiolipin antibodies of the IgG, IgM, and IgA isotypes measured by an ELISA method as described by Gharavi et al (26); 23) renal biopsies categorized according to the modified classification proposed by the World Health Organization (29).

\section{Assessment of disease severity/organ damage}

Disease severity in the 2 groups was examined under the following headings:

1) Number of patients with renal involvement,

2) Number of patients with permanent renal impairment (chronic renal failure-at least 2 samples with serum creatinine $\geq 2.8 \mathrm{mg} / \mathrm{dL}, 6$ months apart, or dialysis requirement),

3) Number of patients with neurologic involvement,

4) Number of patients with severe cardiopulmonary involvement such as myocarditis, endocarditis, myocardial infarction, pneumonitis, pulmonary hypertension, alveolar hemorrhage,

5) Number of patients with osteonecrosis,

6) Number of patients who received $>15 \mathrm{mg} /$ day of prednisone,

7) Number of patients who received cytotoxic agents (mainly azathioprine and/or cyclophosphamide),

8) Number of patients who required dialysis,

9) Number of patients who underwent renal transplantation,

10) Mortality and causes of death.

\section{Statistical analysis}

Data are presented as mean \pm standard error of mean and as percentages. Differences between means and proportions were established using the 2-tailed Mann-Whitney U-test, $\chi^{2}$, or the Fisher exact test where appropriate, uncorrected for multiple comparisons. Statistical significance was set at alpha level $\leq 0.05$.

\section{Results}

\section{General characteristics}

The entire cohort consisted of 1,316 patients: 107 (8.2\%) men and 1,209 (91.8\%) women (female:male ratio, 11:1). The mean age at the time of diagnosis was 26 years (range, 7-76 yr) for male patients and 28 years (range, 5-78 yr) for female patients. The interval between the time of onset and the diagnosis of SLE was 6 months in male and 8 months in female patients. No clinical signs of any disturbance in sexual development were observed in any patient, although neither sex hormone studies nor karyotypes were performed. There were no significant differences between Colombian and Mexican males except for the prevalence of alopecia which was more frequent in the Colombian group (56\% versus $6 \%$, $\mathrm{p}<0.0001$ ), and vascular thrombosis which was more frequent in the Mexican group (32\% versus $11 \%, \mathrm{p}=0.01$ ). Table 1 lists the main clinical findings from both groups.

\section{Clinical and laboratory manifestations}

Table 2 summarizes the prevalence of the main clinical findings observed in the patients at any time during the course of their disease. The 3 most common clinical features in males were arthritis, skin involvement, and renal disease, while in females these were arthritis, skin involvement, and Raynaud phenomenon. Renal involvement and vascular thrombosis were observed in male patients at a significantly higher rate than in female patients, while Raynaud phenomenon occurred less frequently. The occurrence of other clinical features did not differ significantly between the groups.

Table 3 lists the laboratory findings from our patients. Antinuclear antibodies were detected at some time during the course of the illness in all patients. The only statistically significant difference between the 2 groups was the presence of anti-dsDNA antibodies, which was higher in male than in female patients. The prevalence of other laboratory findings was similar in both groups.

TABLE 1. Main clinical findings in 107 Colombian and Mexican male patients with SLE

\begin{tabular}{lcc}
\hline & $\begin{array}{c}\text { Colombia } \\
(\mathrm{n}=73) \\
\%\end{array}$ & $\begin{array}{c}\text { Mexico } \\
(\mathrm{n}=34) \\
\%\end{array}$ \\
\hline Skin involvement & 64 & 59 \\
Alopecia & $56^{*}$ & 6 \\
Raynaud & 30 & 24 \\
Renal involvement & 64 & 44 \\
Seizures & 15 & 6 \\
Psychosis & 4 & 3 \\
Pleuritis & 40 & 35 \\
Pericarditis & 16 & 15 \\
Vascular thrombosis & 11 & $32^{*}$ \\
Hemolytic anemia & 18 & 12 \\
Thrombocytopenia & 22 & 18 \\
Leukopenia & 40 & 32 \\
Osteonecrosis & 5 & 9 \\
Anti-dsDNA & 63 & 41 \\
Prednisone $\geq 15$ mg/day & 90 & 100 \\
Cytotoxics & 33 & 41 \\
\hline
\end{tabular}

$* \mathbf{p}<0.05$.

Abbreviations: SLE $=$ systemic lupus erythematosus. 
TABLE 2. Clinical manifestations in 1,316 male and female patients with SLE

\begin{tabular}{lccl}
\hline & $\begin{array}{c}\text { Men } \\
(\mathrm{n}=107) \\
\%\end{array}$ & $\begin{array}{c}\text { Women } \\
(\mathrm{n}=1,209)\end{array}$ & $\mathrm{p}$ Value \\
& $\%$ & 88 & 0.5 \\
\hline Arthritis & 85 & 5 & 0.6 \\
Jaccoud & 6 & 67 & 0.3 \\
Skin involvement & 62 & 46 & 0.0002 \\
Raynaud & 28 & 44 & 0.004 \\
Renal involvement & 58 & 11 & 0.7 \\
Seizures & 12 & 8 & 0.1 \\
Psychosis & 4 & 36 & 0.6 \\
Pleuritis & 38 & 13 & 0.4 \\
Pericarditis & 16 & 11 & 0.03 \\
Vascular thrombosis & 18 & 11 & 0.1 \\
Hemolytic anemia & 16 & 20 & 0.8 \\
Thrombocytopenia & 21 & 39 & 0.8 \\
Leukopenia & 37 & &
\end{tabular}

\section{Assessment of disease severity/organ damage}

The prevalence of renal disease (including nephrotic syndrome) and the need for moderate to high doses of prednisone ( $\geq 15 \mathrm{mg} /$ day) was significantly higher in male than in female patients (Table 4). Moreover, the prevalence of neurologic involvement, osteonecrosis, and severe cardiopulmonary involvement and the need for cytotoxic agents, dialysis, and renal transplantation were higher in the male group, although the differences were not statistically significant. Mortality was also higher in the males, although the difference was not statistically significant. Ten men and 94 women died during the course of the study. Table 5 lists the causes of death in both groups. Males died more frequently from SLE-related complications (8/10), with lupus nephritis being the principal cause of death compared with the female group. Two of the 10 males died of infections (pulmonary tuberculosis and sepsis due to enterococcus).

Renal involvement was seen in 62 male (58\%) and 527 female (44\%) patients, with nephrotic syndrome

TABLE 3. Serologic findings in male and female patients with SLE

\begin{tabular}{lccl}
\hline & $\begin{array}{c}\text { Men } \\
(\mathrm{n}=107) \\
\%\end{array}$ & $\begin{array}{c}\text { Women } \\
(\mathrm{n}=1,209) \\
\%\end{array}$ & $\mathrm{p}$ Value \\
\hline ANA & 100 & 99 & 1 \\
Anti-dsDNA & 54 & 37 & 0.002 \\
Anti-Sm & 19 & 15 & 0.6 \\
Anti-RNP & 25 & 32 & 0.5 \\
Anti-Ro/SSA & 25 & 26 & 1 \\
Anti-La/SSB & 19 & 17 & 0.8 \\
IgG aCL & 27 & 31 & 0.7 \\
IgM aCL & 16 & 24 & 0.3 \\
IgA aCL & 19 & 22 & 1 \\
\hline
\end{tabular}

Abbreviations: ANA = antinuclear antibodies.
TABLE 4. Variables of disease severity/organ damage in patients with SLE

\begin{tabular}{lccl}
\hline & $\begin{array}{c}\text { Men } \\
(\mathrm{n}=107) \\
\%\end{array}$ & $\begin{array}{c}\text { Women } \\
(\mathrm{n}=1,209) \\
\%\end{array}$ & $\mathrm{p}$ Value \\
& 58 & 44 & 0.004 \\
Renal involvement & 31 & 22 & 0.04 \\
Nephrotic syndrome & 11 & 9 & 0.5 \\
Chronic renal failure & 26 & 22 & 0.3 \\
Neurologic involvement & 21 & 16 & 0.2 \\
Cardiopulmonary involvement & 7 & 4 & 0.2 \\
Osteonecrosis & 93 & 85 & 0.01 \\
Prednisone $\geq 15 \mathrm{mg} /$ day & 36 & 28 & 0.09 \\
Cytotoxics & 11 & 6 & 0.1 \\
Dialysis & 6 & 4 & 0.5 \\
Renal transplantation & 9.3 & 7.7 & 0.6 \\
Mortality & & & \\
\hline
\end{tabular}

seen more frequently in the male than female group ( $31 \%$ versus $22 \%$, respectively, $p=0.04$ ). The occurrence of chronic renal failure and the need for dialysis as well as renal transplantation tended to be more frequent in males, but the difference was not statistically significant. Renal histology was available for 351 SLE patients, 37 males and 314 females ( $51 \%$ versus $26 \%$, respectively, $\mathrm{p}=0.06$ ). Table 6 outlines the prevalence of the different histologic manifestations. Diffuse proliferative glomerulonephritis was the most common pathologic feature in both groups.

\section{Discussion}

Clinical studies have consistently demonstrated that females make up nearly $90 \%$ of all SLE cases, especially women of childbearing age. Men account for $4 \%-22 \%$ of most large series of patients with SLE $(3,14,27,32,50,55)$. In our study males were roughly $8 \%$ of the total cohort of lupus patients, with a female:male ratio of 11:1, a frequency similar to that observed by others $(14,27,32,55)$. The absence of significant differences between the 2 groups with

TABLE 5. Causes of death in 104 patients with SLE

\begin{tabular}{lcc}
\hline & $\begin{array}{c}\text { Men } \\
(\mathrm{n}=10) \\
\text { No. }(\%)\end{array}$ & $\begin{array}{c}\text { Women } \\
(\mathrm{n}=94) \\
\text { No. }(\%)\end{array}$ \\
\hline SLE-related & $8(80)^{*}$ & $37(39)$ \\
$\quad$ Lupus nephritis & - & 15 \\
CNS lupus & - & 5 \\
Cardiac & 1 & 8 \\
Pulmonary & 1 & 1 \\
Hemorrhage due to thrombocytopenia & - & 2 \\
GI vasculitis & - & 1 \\
Hepatic failure & $2(20)$ & $24(26)$ \\
Infection & - & $33(35)$ \\
Miscellaneous $\dagger /$ Unknown & & \\
\hline$*$ p < 0.05. &
\end{tabular}


TABLE 6. Histologic findings in 351 renal biopsies

\begin{tabular}{lccc}
\hline & $\begin{array}{c}\text { Men } \\
(\mathrm{n}=37) \\
\%\end{array}$ & $\begin{array}{c}\text { Women } \\
(\mathrm{n}=314) \\
\%\end{array}$ & $\mathrm{p}$ Value \\
\hline Mesangial GN & 11 & 5 & 0.1 \\
Focal proliferative GN & 5 & 8 & 1 \\
Diffuse proliferative GN & 59 & 60 & 0.7 \\
Membranous GN & 14 & 10 & 0.4 \\
Sclerosis & 11 & 17 & 0.6 \\
\hline
\end{tabular}

Abbreviations: GN = glomerulonephritis.

regard to time intervals from disease onset to diagnosis suggests that there is no delay in diagnosis of the disease in males. The mean age at the time of diagnosis did not differ in the groups, although some authors have reported the onset of the disease in males at an older age $(19,32,40,65,72)$.

\section{Clinical manifestations}

The prevalence of renal disease and vascular thrombosis was statistically higher in the male than the female group. In addition, the prevalence of CNS involvement, osteonecrosis, and severe cardiopulmonary involvement was higher in males, although the differences were not statistically significant. On the other hand, the prevalence of Raynaud phenomenon was lower in the male than the female group; similar findings were also observed (19) in Thai SLE patients.

Previous studies have noted gender-associated differences in a variety of individual clinical manifesta- tions. For example, several investigators have found thrombocytopenia and autoimmune hemolytic anemia $(4,18,39,59,64)$ as well as serositis $(7,14,18,46$, $59,64)$ to be more common in male lupus patients. In a review of 52 male lupus patients, Kaufman et al (39) found an increased prevalence of thrombocytopenia and renal disease without any other notable differences in clinical, laboratory, and serologic parameters. In a study by Miller et al (46) (51 males), pleuritis was more common in males compared with matched female lupus patients, while alopecia, photosensitivity, thrombocytopenia, and neurologic involvement were less common. In a review of 49 Israeli males, Sthoeger and colleagues (64) found a higher frequency of neurologic involvement, nephritis, thrombocytopenia, vasculitis, serositis, and hepatosplenomegaly in male SLE patients. Hochberg et al (32) noted no significant differences in the clinical and laboratory manifestations between 12 male and 138 female patients except for a higher prevalence of peripheral neuropathy in the male group. Ward and Studenski (72) compared 62 males with 299 females, and after adjusting for differences in age, race, and duration of follow-up, they found that male lupus patients had seizures more commonly and tended to progress to renal failure more often than females. Recently Koh et al (40) studied 61 Oriental males compared with 86 Oriental female SLE patients and found a lower prevalence of arthritis and leukopenia in males. The prevalence of the main clinical and laboratory manifestations of the most relevant series of males with SLE appears in Table 7.

TABLE 7. Main clinical and laboratory features in male patients with SLE, present and previous studies

\begin{tabular}{|c|c|c|c|c|c|c|c|}
\hline & $\begin{array}{c}\text { Present Study } \\
(\mathrm{n}=107) \\
\%\end{array}$ & $\begin{array}{c}\text { Ref. } 14 \\
(\mathrm{n}=92) \\
\%\end{array}$ & $\begin{array}{c}\text { Ref. } 72 \\
(\mathrm{n}=62) \\
\%\end{array}$ & $\begin{array}{c}\text { Ref. } 40 \\
(\mathrm{n}=61) \\
\%\end{array}$ & $\begin{array}{c}\text { Ref. } 39 \\
(\mathrm{n}=52) \\
\%\end{array}$ & $\begin{array}{c}\text { Ref. } 46 \\
(\mathrm{n}=51) \\
\%\end{array}$ & $\begin{array}{c}\text { Ref. } 64 \\
(\mathrm{n}=49) \\
\%\end{array}$ \\
\hline Arthritis & 85 & 74 & 71 & 54 & 94 & 94 & 84 \\
\hline Malar rash & 51 & 49 & 27 & 56 & 40 & 24 & 55 \\
\hline Discoid lupus & 9 & 13 & 10 & 15 & 15 & 6 & 33 \\
\hline Raynaud & 28 & 30 & $?$ & $?$ & 25 & 50 & 14 \\
\hline Nephritis & 58 & 48 & 45 & 72 & 65 & 44 & 67 \\
\hline Neuropsychiatric & 26 & $?$ & 25 & 25 & 42 & 18 & 53 \\
\hline Pleuritis & 38 & 72 & 65 & 8 & 33 & 72 & 41 \\
\hline Hemolytic anemia & 16 & 25 & 42 & 10 & 13 & 8 & $?$ \\
\hline Leukopenia & 37 & 8 & 33 & 36 & 44 & 46 & 51 \\
\hline Thrombocytopenia & 21 & 26 & 21 & 36 & 40 & 8 & 43 \\
\hline Anti-dsDNA & 54 & 86 & 61 & 92 & 70 & 64 & 69 \\
\hline Anti-Sm & 19 & 13 & 18 & 10 & 23 & $?$ & $?$ \\
\hline Anti-RNP & 25 & 9 & 20 & 21 & 21 & $?$ & $?$ \\
\hline Anti-Ro & 25 & 15 & $?$ & 0 & 18 & $?$ & $?$ \\
\hline Anti-La & 19 & 13 & 22 & 18 & 5 & $?$ & $?$ \\
\hline IgG aCL & 27 & 21 & $?$ & $?$ & $?$ & $?$ & $?$ \\
\hline IgM aCL & 16 & 17 & $?$ & $?$ & $?$ & $?$ & $?$ \\
\hline IgA aCL & 19 & $?$ & $?$ & $?$ & $?$ & $?$ & $?$ \\
\hline
\end{tabular}

Abbreviations: ? = data not provided; Ref. = reference number. 


\section{Serologic findings}

In regard to serologic findings, the only statistically significant difference between male and female groups was the presence of anti-dsDNA antibodies, which was higher in males. This finding correlates well with the higher prevalence of renal disease seen in males, supporting the relationship between renal disease and anti-dsDNA antibodies (30). Fries and Holman (25) also found a higher prevalence of this autoantibody in males. Koh et al (40) found a lower prevalence of anti-Ro/SSA antibodies in Oriental males compared to females (21\% versus $67 \%$ ), a finding the Moutsopoulos group (21) reported previously. In our study, however, the prevalence of this autoantibody was $25 \%$ in males and $26 \%$ in females. Even though the prevalence of vascular thrombosis was higher in the male group, there were no significant differences in regard to the presence of anticardiolipin antibodies. Others $(5,54,62)$ also have observed a higher prevalence of thrombotic events in male patients with lupus compared to female SLE patients, with or without anticardiolipin antibodies. Specker et al (62) found that 57\% of the male SLE patients they studied experienced more than 30 thromboembolic events, in contrast to 9 events in $6 \%$ of the females $(\mathrm{p}<0.05)$.

\section{Renal disease}

In agreement with most of the studies, we found a higher prevalence of renal disease in the male than the female group (58\% versus $44 \%$, respectively, $\mathrm{p}=$ 0.004 ), although the prevalence of chronic renal failure did not differ in the groups as the prevalence of diffuse proliferative lupus nephritis. Perhaps the most interesting and consistent finding in the analysis of gender differences in SLE is the demonstration of a higher prevalence of renal disease in male patients, in both the adult and pediatric population (11, $12,16,21,24,39,50,62,69,70)$, and a poorer survival rate. However, some studies do not support this view $(14,32,40,46,53)$. The preponderance of female patients in nearly all SLE series has made it difficult to assess any gender difference in the severity of lupus nephritis. In addition to a higher prevalence of renal involvement, several studies point to a poorer renal outcome in male patients $(6,8,12,24,35,36$, $49,56,68,70$ ). Baldwin and colleagues (8) found a higher prevalence of diffuse proliferative lupus nephritis in males. Moreover, Pollak and coworkers (56) found that $79 \%$ of males had active glomerular disease, compared with $49 \%$ of their female counterparts. Tateno et al (69) demonstrated that SLE in males was accompanied by more active nephritis, although it followed a benign course with therapy. Kaufman et al (39) found that $76 \%$ of 52 male lupus patients showed clinically active renal disease. Cel- ermajer and colleagues (12) stated that $67 \%$ of young male subjects had diffuse proliferative lupus nephritis, in contrast to $22 \%$ of young female subjects. Wallace et al (70) found more nephritis and hypocomplementemia and a worse prognosis among male patients compared with female patients. Blum et al (11) reported the presence of renal failure in $47 \%$ of their male patients. Others $(6,24,35,72)$ have also suggested an increased risk of renal failure in males. For example, Austin and colleagues (6) noted male gender as a sign of poor prognosis in patients with lupus nephritis, and Ward and Studenski (72) showed an increased risk of renal failure in males. Iseki et al (35) analyzed 566 SLE patients (51 males, 9\%); 51 lupus patients were considered to have endstage lupus nephritis. The authors also found that male patients had significantly poorer renal survival with a significantly higher risk of developing endstage lupus nephritis. Jonsson et al (36) also reported poorer renal survival among male SLE patients. The gender difference in renal survival (better outcome in females) was also seen in cases of idiopathic membranous glomerulopathy $(20,33)$.

Survival in male SLE patients also tends to be significantly lower than that reported for females $(16,24,28,39,59,65,70,71)$. Folomeev and Alekberova (24) analyzed the survival pattern in 120 Russian male patients with SLE and found that 27 (22.5\%) patients died during the follow-up period, with endstage lupus nephritis being the most common cause of death (63\%). The survival at 5, 10, and 15 years was lower in the male group compared to female patients. Recently, Ward et al (71) analyzed the associations of some demographic factors with long-term survival (mean duration of follow-up, 11 years) in a cohort of 408 lupus patients, 69 of whom were males. They found that males had a higher total mortality rate than females, although SLE-related mortality rates did not differ by sex. In our study, we found that males had higher SLE-related mortality (especially due to renal involvement), although the total mortality did not differ by sex. These findings confirm that renal involvement is a major cause of morbidity and mortality in SLE patients $(2,27,44$, $48,60,70$ ), particularly males.

Although our findings are similar to those from most studies, discrepancies with others most likely reflect different biases of ascertainment, including different ethnic and racial groups sampled, single versus multicenter studies, the small number of affected men in the various studies, primary versus tertiary referrals, and problems of ascertainment of clinical features. In an effort to contribute new data from Latin America, we have studied a very large population of SLE patients, perhaps one of the largest series of male lupus patients ever reported. Although they were recruited from 2 different geo- 
graphic locations, both Hispanic populations share similar sociocultural, economic, behavioral, and health service utilization variables, which makes them suitable to be pooled under a single group. In addition, it should be emphasized that both populations of male lupus patients were almost clinically homogeneous since only 2 significant differences were found. Moreover, no major differences in the disease expression seem to occur among Hispanics with SLE from different Latin American countries $(13,15,44)$. However, further immunogenetic studies are needed for a better definition of these populations. Although our design has limitations due to its retrospective fashion and cross-sectional nature, our findings support the overall conclusion that there are gender-associated differences in the clinical manifestations of SLE.

The reasons for this apparently gender-related variability in SLE expression are not well understood. It is likely that these differences are multifactorial in origin $(1,10,41)$. Hormonal and other factors, including genetic and educational background and compliance, may explain these differences.

\section{Summary}

Clinical and laboratory features were analyzed in 107 Latin American male patients with systemic lupus erythematosus (SLE) who were compared with a group of 1,209 Latin American female patients with SLE to determine the presence of gender-associated differences. Males had an increased prevalence of renal disease, vascular thrombosis, and the presence of anti-dsDNA antibodies, as well as the use of moderate to high doses of corticosteroids, compared with female SLE patients. Although there was no difference in mortality from all causes, SLE-related mortality was higher in the male group. All these findings are consistent with a more severe disease in Latin American males than in female patients from the same region.

\section{Acknowledgments}

The authors thank Dr. Luis R. Espinoza for his critical review and valuable suggestions; Dr. Jorge Henao for providing data on dialysis and renal transplantation; and Beatríz Tobón and Anne Compliment for typing and preparing the manuscript.

\section{References}

1. Abraham A, Petri M. Lack of coping and control over illness in systemic lupus erythematosus (SLE) subgroups with poor outcomes. Arthritis Rheum 38(Suppl): S326, 1995.

2. Abu-Shakra M, Urowitz MB, Gladman DD, Gough J. Mortality studies in systemic lupus erythematosus. Results from a single center. II. Predictor variables for mortality. J Rheumatol 22: 1265-70, 1995.
3. Alarcon-Segovia D, Deleze M, Oria CV, Sanchez-Guerrero J, GomezPacheco L, Cabiedes J, Fernandez L, Ponce de Leon S. Antiphospholipid antibodies and the antiphospholipid syndrome in systemic lupus erythematosus. A prospective analysis of 500 consecutive patients. Medicine (Baltimore) 68: 353-65, 1989.

4. Alger M, Alarcon-Segovia D, Rivero SJ. Hemolytic anemia and thrombocytopenic purpura: Two related subsets of lupus erythematosus. J Rheumatol 4: 351-57, 1977.

5. Aranow C, Giudice J, Weinstein A, Barland P. Case-control study of disease severity in men and women with systemic lupus erythematosus. Arthritis Rheum 37(Suppl): S181, 1994.

6. Austin HA, Muenz LR, Joyce KM, Antonovych TA, Kullick ME, Klippel JH, Decker JL, Balow JE. Prognostic factors in lupus nephritis: Contribution of renal histologic data. Am J Med 75: 382-91, 1983.

7. Aydintug AO, Domenech I, Cervera R, Khamashta MA, Jedryka-Goral A, Vianna JL, Hughes GRV. Systemic lupus erythematosus in males: Analysis of clinical and laboratory features. Lupus 1: 295-98, 1992.

8. Baldwin DS, Lowenstein J, Rothfield NF, Gallo G, McCluskey RT. The clinical course of the proliferative and membranous forms of lupus nephritis. Ann Intern Med 73: 929-42, 1970.

9. Ballou SP, Khan MA, Kushner I. Clinical features of systemic lupus erythematosus: Differences related to race and age of onset. Arthritis Rheum 25: 55-60, 1982.

10. Bell DA, Rigby R, Stiller CR, Clark WF, Harth M, Ebers G. HLA antigens in systemic lupus erythematosus: Relationship to disease severity, age at onset and sex. J Rheumatol 11: 475-79, 1984.

11. Blum A, Rubinow A, Galun E. Predominance of renal involvement in male patients with systemic lupus erythematosus. Clin Exp Rheumatol 9: 206-7, 1991.

12. Celermajer DS, Thorner PS, Baumal R, Arbus GS. Sex differences in childhood lupus nephritis. Am J Dis Child 138: 586-88, 1984.

13. Catoggio LJ. Systemic lupus erythematosus in Argentina: An overview. Lupus 2: 3-7, 1993.

14. Cervera R, Khamashta MA, Font J, Sebastiani GD, Gil A, Lavilla P, Domenech I, Aydintug AO, Jedryka-Goral A, De Ramon E, Galeazzi M, Haga HJ, Mathieu A, Houssiau F, Ingelmo M, Hughes GRV. Systemic lupus erythematosus: Clinical and immunologic patterns of disease expression in a cohort of 1,000 patients. Medicine (Baltimore) 72: 113$24,1993$.

15. Chahade WH, Sato EI, Moura JE Jr, Costallat LTL, Andrade LEC. Systemic lupus erythematosus in Sao Paulo/Brazil: A clinical and laboratory overview. Lupus 4: 100-3, 1995.

16. Chang CC, Shih TY, Chu SJ, Kuo SY, Chen CM, Hsu CM, Chang ML, Chang DM. Lupus in chinese male: A retrospective study of 61 patients. Chin Med J 55: 143-50, 1995.

17. Cleland LG, Bell DA, Willans M, Saurino BC. Familial lupus: Family studies of HLA and serologic findings. Arthritis Rheum 21: 183-91, 1978.

18. Costallat LTL, Coimbra AMV. Systemic lupus erythematosus in 18 Brazilian males: Clinical and laboratory features. Clin Rheumatol 12: 522$25,1993$.

19. Deesomechok U, Tumrasvin T. Clinical features of SLE in Thai males and females. J Med Assoc Thai 75: 133-40, 1992.

20. Donadio JV Jr, Torres VE, Velosa JA, Wagoner RD, Holley KE, Okamura M, Ilstrup DM, Chu CP. Idiopathic membranous nephropathy: The natural history of untreated patients. Kidney Int 33: 708-15, 1988.

21. Drosos AA, Dimou GS, Tzioufas AG, Galanopoulou V, SiamopoulouMavridou A, Moutsopoulos HM. Systemic lupus erythematosus in Greek men. Lupus 1(Suppl 1): 122, 1992.

22. Dubois EL, Kaplan BJ. S.L.E. and Klinefelter's syndrome [letter]. Lancet 1: 93,1976

23. Fam AG, Izsak M, Saiphoo C. Systemic lupus erythematosus and Klinefelter's syndrome [letter]. Arthritis Rheum 23: 124-26, 1980.

24. Folomeev M, Alekberova Z. Survival pattern of 120 males with systemic lupus erythematosus. J Rheumatol 17: 856-58, 1990.

25. Fries J, Holman H. Systemic lupus erythematosus: A clinical analysis. Philadelphia: WB Saunders, 1975.

26. Gharavi AE, Harris EN, Asherson RA, Hughes GRV. Anticardiolipin antibodies: Isotype distribution and phospholipid specificity. Ann Rheum Dis 46: 1-6, 1987.

27. Ginzler EM, Diamond HS, Weiner M, Schlesinger M, Fries JF, Wasner C, Medsger TA Jr, Ziegler G, Klippel JH, Hadler NM, Albert DA, Hess HV, Spencer-Green G, Grayzel A, Worth D, Hahn BH, Barnett EV. A multicenter study of outcome in systemic lupus erythematosus. I. Entry variables as predictors of prognosis. Arthritis Rheum 25: 601-11, 1982.

28. Gomez-Reino J, Blanco F, Gonzalez MR, Corrales A, Rodriguez V, Rosas JC, Gomez EP. Survival analysis of 306 Spanish patients with systemic lupus erythematosus. Arthritis Rheum 37(Suppl): S327, 1994. 
29. Grishman E, Gerber MA, Churg J. Patterns of renal injury in systemic lupus erythematosus: Light and immunofluorescence microscopic observations. Am J Kid Dis 2(Suppl 1): 135-41, 1982.

30. Harley JB. Autoantibodies are central to the diagnosis and clinical manifestations of lupus. J Rheumatol 21: 1183-85, 1994.

31. Hochberg M. Lupus erythematosus: The epidemiology of lupus erythematosus. In: Wallace D, Hahn B, eds. Dubois' lupus erythematosus. 4th ed. Philadelphia: Lea \& Febiger, pp 49-57, 1993.

32. Hochberg MC, Boyd RE, Ahearn JM, Arnett FC, Bias WB, Provost TT, Stevens MB. Systemic lupus erythematosus: A review of clinicolaboratory features and immunogenetic markers in 150 patients with emphasis on demographic subsets. Medicine (Baltimore) 64: 285-95, 1985.

33. Hopper J Jr, Trew PA, Biava CG. Membranous nephropathy: Its relative benignity in women. Nephron 29: 18-24, 1981.

34. Inman RD. Immunologic sex differences and the female predominance in systemic lupus erythematosus. Arthritis Rheum 21: 849-52, 1978

35. Iseki K, Miyasato F, Oura T, Uehara H, Nishime K, Fukiyama K. An epidemiologic analysis of end-stage lupus nephritis. Am J Kidney Dis 23: 547-54, 1994.

36. Jonsson H, Nived O, Sturfelt G. Outcome in systemic lupus erythematosus: A prospective study of patients from a defined population. Medicine (Baltimore) 68, 141-50, 1989

37. Jungers P, Dougados M, Pelissier C, Kuttenn F, Tron F, Lesavre P, Bach JF. Influence of oral contraceptive therapy on the activity of systemic lupus erythematosus. Arthritis Rheum 25: 618-23, 1982.

38. Jungers P, Kuttenn F, Liote F, Pelissier C, Athea N, Laurent MC, Viriot J, Dougados M, Bach JF. Hormonal modulation in systemic lupus erythematosus: Preliminary clinical and hormonal results with cyproterone acetate. Arthritis Rheum 28: 1243-50, 1985.

39. Kaufman LD, Gomez-Reino JJ, Heinicke MH, Gorevic PD. Male lupus: Retrospective analysis of the clinical and laboratory features of 52 patients, with a review of the literature. Semin Arthritis Rheum 18 189-97, 1989.

40. Koh WH, Fong KY, Boey ML, Feng PH. Systemic lupus erythematosus in 61 Oriental males. A study of clinical and laboratory manifestations. Br J Rheum Dis 33: 339-42, 1994.

41. Lahita RG. Sex, age, and systemic lupus erythematosus. In: Lahita RG, ed. Systemic lupus erythematosus. 2nd ed. New York: John Wiley, pp. $527-42,1993$.

42. Lahita RG, Chiorazzi N, Gibofsky A, Winchester RJ, Kunkel HG. Familial systemic lupus erythematosus in males. Arthritis Rheum 26: 3944, 1983.

43. Masi AT, Kaslow RA. Sex effects in systemic lupus erythematosus: A clue to pathogenesis. Arthritis Rheum 21: 480-84, 1978.

44. Massardo L, Martinez ME, Jacobelli S, Villarroel L, Rosenberg H, Rivero S. Survival of chilean patients with systemic lupus erythematosus. Semin Arthritis Rheum 24: 1-11, 1994.

45. Meislin AG, Rothfield NF. Systemic lupus erythematosus in childhood. Pediatrics 42: 37-49, 1968.

46. Miller MH, Urowitz MB, Gladman DD, Killinger DW. Systemic lupus erythematosus in males. Medicine (Baltimore) 62: 327-34, 1983.

47. Mills JA. Systemic lupus erythematosus. N Engl J Med 330: 1871-79, 1994.

48. Molina J, Molina JF, Drenkard C, Cardiel MH, Uribe O, Felipe O, Ramirez LA, Alarcon-Segovia D. Systemic lupus erythematosus in 1,316 Latin American patients. A multicenter, binational study. Lupus 4(Suppl 2): 40, 1995.

49. Molina JF, Anaya JM, Garcia C, Cuellar ML, Hoffman E, Espinoza LR. Intravenous cyclophosphamide (IVCY) in diffuse proliferative lupus nephritis: A two year follow-up study. Arthritis Rheum 37(Suppl): S180, 1994.

50. Molina JF, Gomez LJ, Molina J. Systemic lupus erythematosus in 63 Colombian males. Rev Colomb Reum 1: 15-21, 1993.

51. Molina JF, Gutierrez SR, Espinoza LR, Gedalia A, Malagón C, Uribe O, Molina J. Chilhood-onset SLE in 166 patients: A comparative study of
African Americans and Latin Americans. Arthritis Rheum 38(Suppl): S363, 1995 .

52. Morley KD, Parke A, Hughes GRV. Systemic lupus erythematosus: Two patients treated with danazol. Br Med J 284: 1431-32, 1982

53. Pande I, Malaviya AN, Sekharan NG, Kailash S, Uppal SS, Kumar A. SLE in Indian men: Analysis of the clinical and laboratory features with a review of the literature. Lupus 3: 181-86, 1994.

54. Petri M, Hellmann D, Hochberg M, Meyerhoff J, Bell W, Goldman D. Arterial thrombotic events (TE) in SLE: The Baltimore lupus cohort study. Lupus 4(Suppl 2): 175, 1995.

55. Pistner M, Wallace DJ, Nessim S, Metzger AL, Klinenberg JR. Lupus erythematosus in the 1980s: A survey of 570 patients. Semin Arthritis Rheum 21: 55-64, 1991.

56. Pollak VE, Pirani CL, Schwartz FD. The natural history of the renal manifestations of systemic lupus erythematosus. J Lab Clin Med 63 : 537-50, 1964

57. Price WH, MacClean N, Littlewood AP. Systemic lupus erythematosus and Klinefelter's syndrome. Lancet 1: 807, 1976

58. Ramsey-Goldman R. Pregnancy in systemic lupus erythematosus. Clin Rheum Dis 14: 169-85, 1988.

59. Rondinone R, Doria A, Vesco P, Vaccaro E, Ruffatti A, Gambari PF, Todesco S. Clinical manifestations, laboratory findings and survival in male patients with SLE. Lupus 1(Suppl 1): 119, 1992

60. Rosner S, Ginzler EM, Diamond HS, Weiner M, Schlesinger M, Fries JF, Wasner C, Medsger TA Jr, Ziegler G, Klippel JH, Hadler NM, Alber DA, Hess HV, Spencer-Green G, Grayzel A, Worth D, Hahn BH, Barnett EV. A multicenter study of outcome in systemic lupus erythematosus. II. Causes of death. Arthritis Rheum 25: 612-17, 1982.

61. Segami MI, Alarcon-Segovia D. Systemic lupus erythematosus and Klinefelter's syndrome. Arthritis Rheum 20: 1565-67, 1977.

62. Specker C, Becker A, Lakomerk HJ, Bach D, Grabensee B. Systemic lupus erythematosus in men-a different prognosis? Z Rheumatol 53 . $339-45,1994$

63. Steinberg AD, Melez KA, Raveche ES, Patton Reeves J, Boegel WA, Smathers PA, Taurog JD, Weinlein L, Duvic M. Approach to the study of the role of sex hormones in autoimmunity. Arthritis Rheum 22: 1170-76, 1979.

64. Sthoeger ZM, Geltner D, Rider A, Bentwich Z. Systemic lupus erythematosus in 49 Israeli males: A retrospective study. Clin Exp Rheumatol 5: $233-40,1987$.

65. Swaak AJG, Nossent JC, Bronsveld W, Van Rooyen A, Nieuwenhuys EJ, Theuns L, Smeenk RJT. Systemic lupus erythematosus. I. Outcome and survival: Dutch experience with 110 patients studied prospectively. Ann Rheum Dis 48: 447-54, 1989.

66. Swaak AJG, Nossent JC, Bronsveld W, Van Rooyen A, Nieuwenhuys EJ, Theuns L, Smeenk RJT. Systemic lupus erythematosus. II. Observations on the occurrence of exacerbations in the disease course: Dutch experience with 110 patients studied prospectively. Ann Rheum Dis 48: 455-60, 1989.

67. Tan EM, Cohen AS, Fries JF, Masi AT, McShane DJ, Rothfield NF, Schaller JG, Talal N, Winchester RJ. The 1982 revised criteria for the classification of systemic lupus erythematosus. Arthritis Rheum 25: 1271-77, 1982

68. Tareyeva A, Janushkevich TN, Tuganbekova SK. Lupus nephritis in males and females. Proc EDTA 21: 712-16, 1984.

69. Tateno S, Hiki Y, Hamaguchi K, Tsuchida H, Shigeematsu H, Kobayashi Y. Study of lupus nephritis in males. Q J Med 81: 1031-39, 1991.

70. Wallace DJ, Podell T, Weiner J, Klinenberg JR, Forouzesh S, Dubois EL. Systemic lupus erythematosus-survival patterns. Experience with 609 patients. JAMA 245: 934-38, 1981.

71. Ward MM, Pyun E, Studenski S. Long-term survival in SLE. Patient characteristics associated with poorer outcomes. Arthritis Rheum 38: 274-83, 1995.

72. Ward MM, Studenski S. Systemic lupus erythematosus in men. A multivariate analysis of gender differences in clinical manifestations. $\mathbf{J}$ Rheumatol 17: 220-24, 1990. 